\title{
PROJEKTY INNOWACYJNE W PRZEDSIĘBIORSTWACH JAKO POTENCJALNE ŹRÓDŁO RYZYKA FINANSOWEGO
}

\section{Wprowadzenie}

Jednym z ważniejszych celów, które powinny stawiać sobie menedżerowie, jest podnoszenie wartości przedsiębiorstwa ${ }^{1}$. Innowacyjność oraz zdolność do przyciągania utalentowanych ludzi znajdują się na czołowych miejscach wśród czynników przesądzających o tej wartości. Innowacje wdrażane w obrębie strategicznych sfer funkcjonowania przedsiębiorstwa powodują zmniejszenie istniejącej luki technicznej, technologicznej i organizacyjnej, przyczyniając się do poprawy pozycji konkurencyjnej przedsiębiorstwa. Oddziaływanie innowacji dotyczy rozległych sfer, a efekty innowacji powstają $\mathrm{w}$ różnych obszarach, poza przedsiębiorstwem, także w czasie wykraczającym poza czas eksploatacji pojedynczej innowacji. Kreowanie innowacji musi być związane z efektywnym wykorzystaniem dostępnych zasobów, własnych i/lub pozyskanych w celu realizacji zadań przedsiębiorstwa. Jednak nieodłącznym atrybutem procesów innowacyjnych jest ryzyko niepowodzenia. Dotyczy to zwłaszcza innowacji o dużym stopniu oryginalności, których tworzenie i wprowadzanie na rynek odbywa się poza granicami wiedzy oraz doświadczenia projektowego, wytwórczego i marketingowego.

\section{Przebieg procesów innowacyjnych w przedsiębiorstwie}

W literaturze spotkać można różne klasyfikacje strategii innowacji. Występuje więc podział na następujące odmiany strategii²:

1 M. Bacior, Kreowanie wartości firmy jako cel zarządzania wspótczesnym przedsiębiorstwem, CeDeWu, Warszawa 2015.

2 G. Lancaster, L. Massingham, Marketing Management, McGraw-Hill, London 1993, s. 135-138. 
- strategia ofensywna - polega na tworzeniu w firmie warunków stymulujących powstawanie i szybkie wprowadzanie do praktyki nowych rozwiązań; wiąże się to $\mathrm{z}$ wysokimi kosztami i ryzykiem, że pomysły i wynalazki będą mało wartościowe, powstaną zbyt późno lub nie pojawią się nawet wcale;

- strategia defensywna - oparta jest na innowacji, reprezentującej niski poziom oryginalności, przynoszącej małe ryzyko oraz niewielkie ewentualne korzyści; po niskich kosztach wprowadza się na rynek substytuty nowych produktów, oferowanych przez przedsiębiorstwa stosujące strategię ofensywną;

- strategia zasilania zewnętrznego - kupowanie licencji i wyników badań obcych podmiotów;

- strategia wchodzenia w nisze;

- strategia kreowania rynku - jej podstawą są innowacje radykalne, produkty nowe na świecie;

- strategia niezależna - polega na koncentrowaniu wysiłków innowacyjnych na swoim produkcie, unowocześnianiu go i zwiększaniu jego udziału w rynku;

- strategia pozyskiwania specjalistów; kiedy utrudniony jest ewentualny zakup licencji w celu pozyskania technologii firmy konkurencyjnej, kupuje się specjalistów z tego przedsiębiorstwa dysponujących potrzebną wiedzą (know-how) i umiejętnościami;

- strategia pozyskiwania całych przedsiębiorstw, o dużym potencjale innowacyjnym. Ponadto w obszarze strategii ofensywnej można umieścić trzy strategie, będące odmianami innowacji zasilanych zewnętrznie, umożliwiające szybkie rozbudowanie potencjału badań i rozwoju $(\mathrm{B}+\mathrm{R})$ oraz konkurencyjności firmy:

- joint venture - podmioty tworzą wspólne przedsiębiorstwo, licząc na uzyskanie efektu synergii, rozłożenie ryzyka oraz możliwość lepszego i szybszego reagowania na sygnały rynkowe;

- alians integracyjny - zawiązywany głównie pod kątem wykorzystania efektu skali w zakresie jakiegoś podzespołu, stadium procesu wytwarzania lub obsługi rynku; - alians addytywny - w którym sojusz obejmuje szerokie spektrum współdziałania: od badań i rozwoju aż po sprzedaż.

Przygotowania do innowacji i jej wdrożenie muszą być ujęte w ramy ściśle określonych procedur, ponieważ jest to proces skomplikowany, składający się z wielu faz (rys. 1); są to: obserwacja i percepcja stanu środowiska $\rightarrow$ dostrzeżenie problemu lub potrzeby, podstawowa inspiracja dla aktywności innowacyjnej $\rightarrow$ decyzja o podjęciu próby rozwiązania, badania i planowanie nierzadko wraz z „modelem” w skali półprzemysłowej, certyfikatami, dopuszczeniami, patentami (dotyczy zarówno produktu, jak i sposobów produkcji) $\rightarrow$ proces twórczy, powstanie wariantów rozwiązania $\rightarrow$ optymalizacja i wybór wariantu do realizacji $\rightarrow$ aplikacja przyjętego wariantu 
rozwiązania, wdrożenie przemysłowe (obejmuje obszar od budowy zakładu produkcyjnego/centrum usługowego po dojście do zakładanych mocy produkcyjnych i komercjalizację nowego produktu/usługi/technologii) $\rightarrow$ kontrola prawidłowości funkcjonowania $\rightarrow$ rozpowszechnienie.

Rysunek 1. Przebieg procesów innowacyjnych

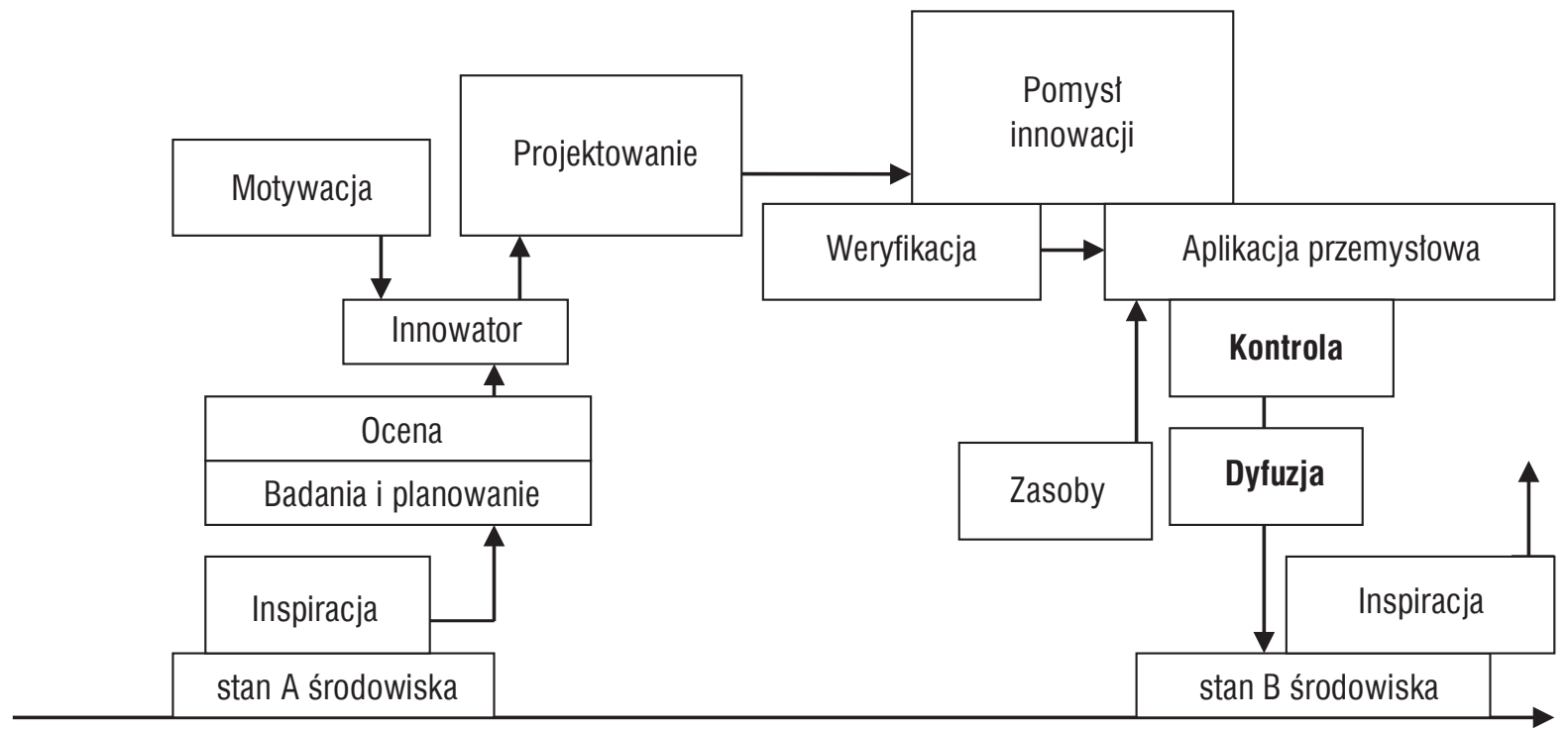

czas

Źródło: Opracowanie własne na podstawie: I. Bielski, Innowacje w kreowaniu zdolności konkurencyjnej przedsiębiorstwa, „Rozprawy” nr 125, Wydawnictwa Uczelniane UTP im. J.J. Śniadeckich w Bydgoszczy, Bydgoszcz 2007, s. 66.

Działania innowacyjne powinny mieć charakter cykliczny, zatem od stanu początkowego A środowiska, w którym określone rozwiązania techniczne i organizacyjne tworzą określony układ relacji, wyzwalający impulsy mogące stać się inspiracją dla zmiany, poprzez wszystkie fazy procesu innowacyjnego prowadzą do stanu B środowiska, który może inspirować kolejne działania innowacyjne.

Zasadnicze znaczenie dla sukcesu nowego produktu przemysłowego mają trzy czynniki:

- wysoce innowacyjne produkty, wykazujące swą wyraźną wyższość nad oferowanymi przez konkurencję;

- znajomość rynku i umiejętności marketingowe;

- techniczna i produkcyjna synergia i biegłość, umożliwiająca sprawne przechodzenie do kolejnych faz procesu rozwoju nowego produktu.

3 R.G. Cooper, The Dimensions of Industrial New Product Succes and Failure, „Journal of Marketing” Vol. 43, Summer 1979, s. 100. 
Zaś trzy główne rodzaje barier w uzyskaniu sukcesu to:

- produkt o relatywnie wysokiej cenie, niezawierający wyrazistych korzyści dla klienta;

- dynamiczny rynek, na który wprowadza się wiele nowych produktów;

- konkurencyjny rynek, na którym klienci są już dobrze zaspokojeni.

Jednocześnie, jak wynika z prawa pierwszeństwa ${ }^{4}$, wyprzedzenie konkurentów w wejściu na rynek, nawet jeśli powoduje przekroczenie budżetu, jest lepsze niż wejście późniejsze, w ramach budżetu. Powodzenie każdej strategii innowacji w dużym stopniu zależy od sprawności jej realizacji, należy jednak podkreślić, że najważniejszy jest wybór właściwych projektów, a dopiero w drugiej kolejności realizowanie ich właściwie ${ }^{5}$. Tym niemniej należy przyjąć, że osiągnięcie dokładnie wyznaczonego celu jest niemożliwe (rys. 2), ponieważ, podobnie jak wymiar nominalny w technice, funkcjonuje on w zbiorze utopii/absolutu, natomiast wynik osiąga się w wymiarze realnym.

Rysunek 2. Uzyskana wartość/jakość jako różnica efektu teoretycznego (pomysłu) i efektu utraconego wskutek niedojrzałości technologii

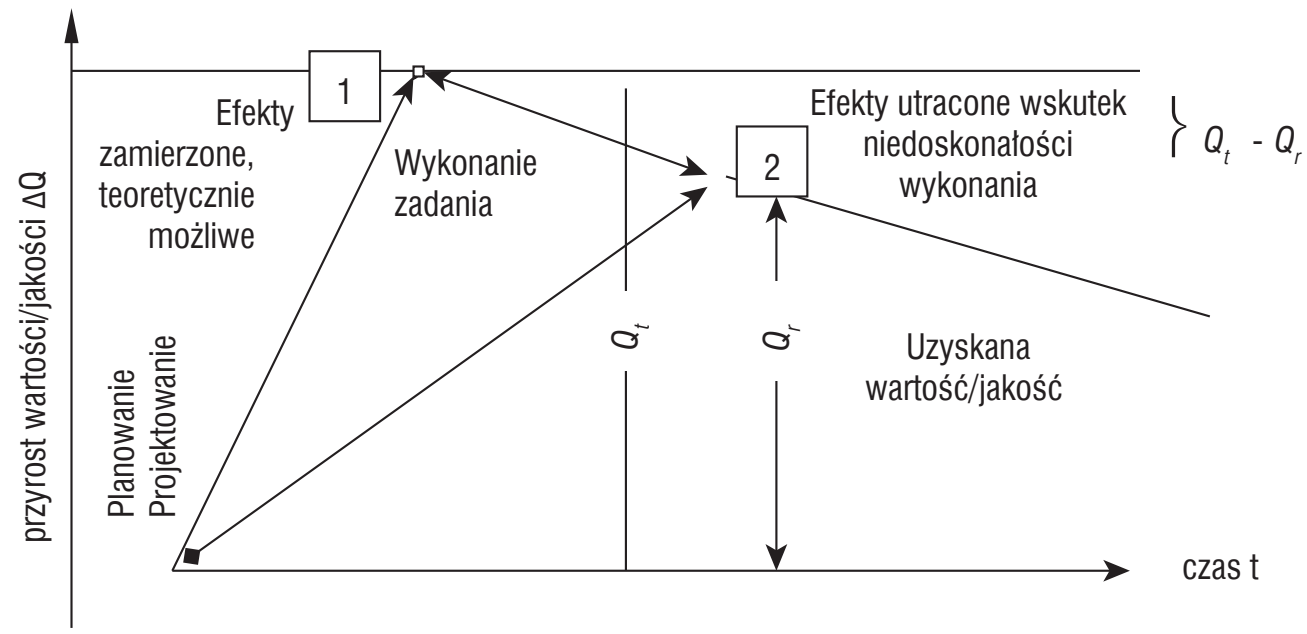

Źródło: Opracowanie własne na podstawie: E. Brzuchowski, Ciągi myśli i czynów, „Mechanik” nr 9, 1983, s. 564.

Możliwość oraz stopień odchylenia od zaplanowanych wartości w głównym stopniu zależą od czasu (rys. 3) i mogą powstawać zarówno w trakcie wdrażania innowacji $\left(t_{r}\right)$, jak i w czasie jej eksploatacji $\left(t_{e}\right)$. Źródłem odchyleń w czasie realizacji przedsięwzięcia mogą być: zawodność techniczna i eksploatacyjna urządzeń,

4 A. Ries, J. Trout, 22 niezmienne prawa marketingu, S. „Marketing bez tajemnic”, PWE, Warszawa 1997, s. 13.

5 R.G. Cooper, Winning at New Products, Addison Wesley, Reading, MA, USA 1993, s. 115. 
niedoskonałość wykonania, działania przypadkowe i celowe przeciwko jakości, ale także pojawienie się nowych źródeł zaopatrzenia, zmiany kosztów zaopatrzenia lub wcześniejsze wdrożenie podobnych projektów przez konkurentów. Zatem już na tym etapie nakłady mogą być większe $\left(A_{1}\right)$ lub mniejsze $\left(A_{3}\right)$ od zaplanowanej wartości $A_{0}$. Może to mieć istotny wpływ na osiągnięcie lub nieosiągnięcie zwrotu nakładów, który zgodnie z planem miał nastąpić po czasie $t_{K}$. W okresie eksploatacji innowacji mogą wystąpić różne zdarzenia, których siła oddziaływania także może zmieniać się w czasie. W przedziale A-B wpływ na odchylenia mogą mieć: czynniki rynkowe, luka informacyjna, zmiany popytu, zmiana sytuacji konkurencyjnej, zmiany wrażliwości otoczenia, rozbieżność pomiędzy charakterem innowacji wdrożonej a charakterem innowacji właściwej dla aktualnej sytuacji rynkowej. W przedziale B-C źródłem odchyleń mogą być: zmiany siły nabywczej, pojawienie się substytutów, działania konkurencji, ale także nowe regulacje prawne lub interwencjonizm państwa. W efekcie - po okresie eksploatacji $t_{e}$ - może okazać się, że zamiast zaplanowanej wartości dodatniej $D_{11}$ efekty innowacji, postrzegane z perspektywy firmy, osiągną wartość ujemną $D_{1}$ lub wartość wyższą od oczekiwanej - maksymalnie $D_{14}$.

Osiągnięcie wysokiego poziomu niezawodności w zakresie polityki produktowej, w szczególności zapewnienie jakości, jest możliwe tylko przy wykorzystaniu sprawdzonych algorytmów postępowania. W tym celu można posłużyć się zestawem pytań: Ile traci firma na usuwanie usterek? Ile kosztuje firmę produkt wybrakowany, usuwanie braków, sortowanie, korespondencja, utrata zaufania? Jak szybko można realizować zamówienia, zapewniając jednocześnie unikanie błędów w produkcji? Czy w pełni uwzględniono w produkcie oczekiwania i życzenia klienta oraz jakie konsekwencje pociąga za sobą sytuacja, w której klient nie jest zadowolony $\mathrm{z}$ dostarczonego produktu?

Podobnie program jakości Six Sigma, który umożliwia zorganizowanie i przeprowadzenie procesów, z założenia wykluczające możliwość powstawania wad i błędów. Wymaga to przyjęcia następujących założeń':

- Nie wiemy, czego nie wiemy.

- Nie możemy poprawić czegoś, o czym nie wiemy.

- Nie dowiemy się, póki nie zmierzymy.

- Nie mierzymy tego, czego nie uznajemy za ważne.

- Nie uznajemy za ważne tego, czego nie mierzymy.

6 M. Harry, R. Schroeder, Six Sigma. Wykorzystanie programu jakości do poprawy wyników finansowych, Dom Wydawniczy ABC Oficyna Ekonomiczna, Kraków 2002. 
Rysunek 3. Zmienność w czasie poziomu ryzyka inwestycyjnego projektów innowacyjnych

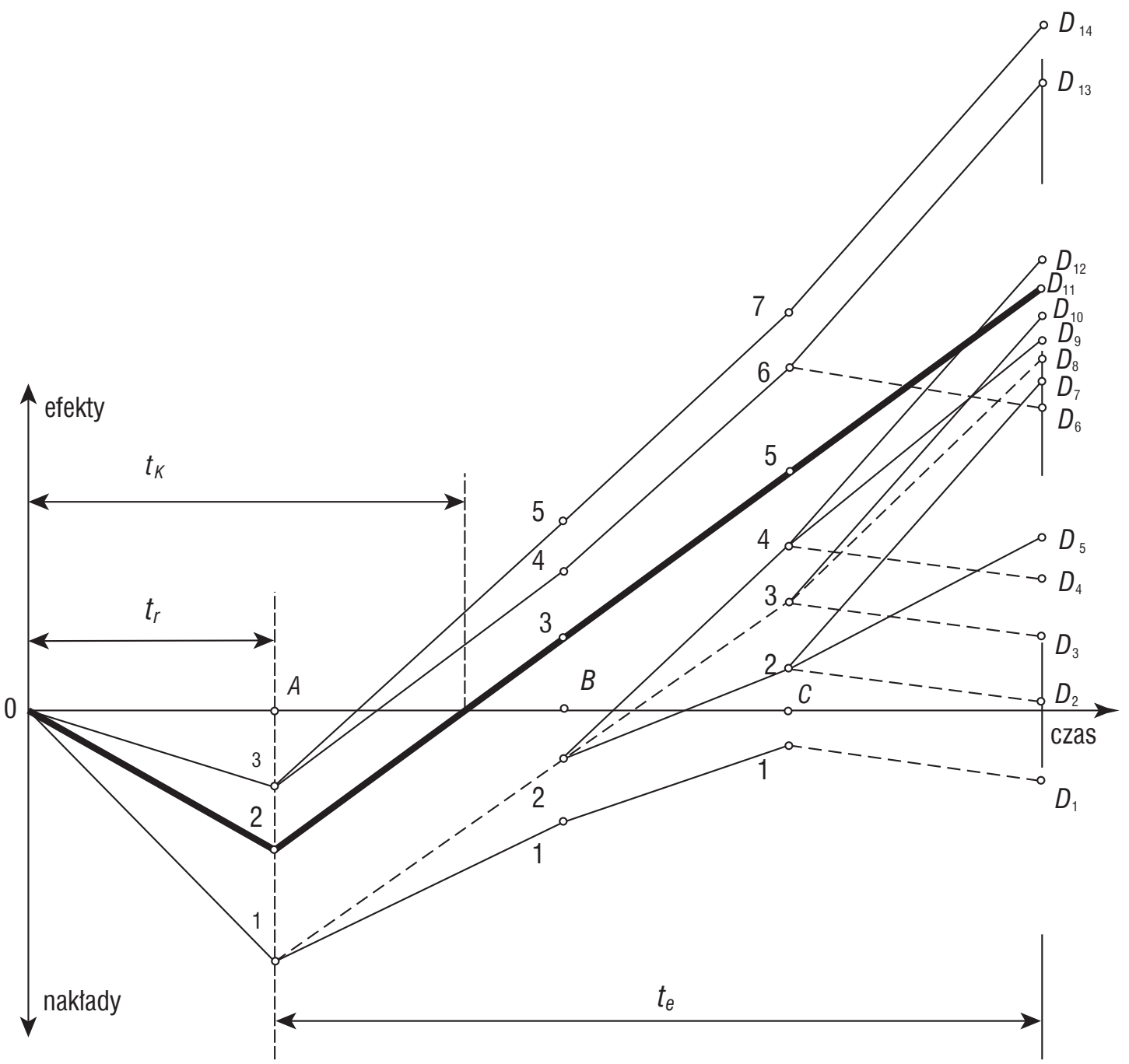

Źródło: Opracowanie własne na podstawie: S.B. Block, G.A. Hirt, Foundations of Financial Management, Irwin, Homewood 1987, s. 409; I. Bielski, Współczesny marketing. Filozofia, strategie, instrumenty, Studio Emka, Warszawa 2006, s. 87.

\section{Oczekiwane efekty i ryzyko procesów innowacyjnych}

Każda działalność gospodarcza musi uwzględniać aktualne i przyszłe warunki gospodarowania, a zatem związana jest z niepewnością i ryzykiem. Niepewność jako zjawisko jest niewymierna i dotyczy przeważnie długich okresów, ryzyko zaś jest zjawiskiem mierzalnym i związanym raczej z krótkimi okresami . Ryzyko określa się jako

7 Efektywność przedsięwzięć rozwojowych, red. R. Borowiecki, Wydawnictwo AE w Krakowie, TNOiK, Warszawa, Kraków 1995, s. 26. 
„prawdopodobieństwo zajścia zdarzenia ocenianego negatywnie”8 lub jako „możliwość nieuzyskania zamierzonych efektów działalności gospodarczej, poniesienia niezamierzonych strat lub nakładów wyższych od przewidywanych"’. Przyjmuje się też, że ryzyko od niepewności odróżnia stan wiedzy decydenta na temat prawdopodobieństwa zajścia określonego zdarzenia. Ze względów psychologicznych korzystniej jest traktować ryzyko jako synonim niepewności, ponieważ ryzyko zazwyczaj kojarzy się z prawdopodobną stratą i powoduje wyłącznie negatywne skojarzenia.

Nowe antycypowane warunki działalności określane są przez wiele składowych, niemożliwych do przewidzenia i trudnych do określenia, a w związku z tym samym utrudnione jest wystarczająco dokładne określenie kierunku i zwrotu siły oddziaływania wypadkowej tych czynników składowych. Problematyka niepewności i ryzyka muszą być uwzględniane zwłaszcza przy podejmowaniu decyzji dotyczących rozwoju przedsiębiorstwa i rozpoczęciu przedsięwzięć inwestycyjnych. Tylko zebranie odpowiednich danych i przetworzenie ich w użyteczne informacje umożliwia odpowiedzialną analizę czynników ryzyka. I chociaż odporność różnych podmiotów gospodarczych na oddziaływanie czynników ryzyka jest różna, to jednak ryzyko występuje zawsze, a jedynym instrumentem pozwalającym obniżyć niebezpieczeństwo błędnej decyzji jest informacja, której poziom przekroczył wartość krytyczną, umożliwiającą obniżenie ryzyka do poziomu akceptowanego przez decydenta. W szczególnym stopniu dotyczy to decyzji dotyczących działalności innowacyjnej. Celem każdej innowacji powinno być osiągnięcie przez przedsiębiorstwo przewagi konkurencyjnej. Innowacje wymagają inwestycji, zatem efektywność ekonomiczną przedsięwzięć innowacyjnych można i należy rozpatrywać przez pryzmat nakładów inwestycyjnych, związanych z realizacją przedsięwzięcia oraz nakładów bieżących ponoszonych w związku $\mathrm{z}$ dostarczeniem na rynek oferty marketingowej o nowym kształcie. W związku z niemożnością przewidzenia z całą pewnością wystąpienia i nasilenia zdarzeń zarówno w trakcie procesów inwestycyjnych, jak i w trakcie eksploatacji innowacji przyjmuje się definiowanie ryzyka jako kombinację częstości lub prawdopodobieństwa określonego zdarzenia niekorzystnego i konsekwencji tego zdarzenia ${ }^{10}$ [PN-IEC 60300-3-9] lub możliwość powstawania odchyleń od przewidywanych efektów działalności ${ }^{11}$.

8 T. Pszczołowski, Mała encyklopedia prakseologii i teorii organizacji, Ossolineum, Wrocław, Warszawa 1978, s. 215.

9 A. Ehrlich, Ryzyko gospodarcze, w: Encyklopedia organizacji i zarzadzania, PWE, Warszawa 1981, s. $456-457$.

10 PN-IEC 60300-3-9, 1999.

11 J. Czekaj, Z. Dresler, Podstawy zarządzania finansami firm, PWN, Warszawa 1995, s. 38. 
Źródłem ryzyka są czynniki:

- makroekonomiczne (postęp techniczny, regulacje prawne, stopa wzrostu PKB, inflacja, zmiany elastyczności krzyżowej popytu, zmiany socjodemograficzne itp.);

- mikroekonomiczne (ryzyko rynkowe, pojawienie się lub znikanie dominującego konkurenta, zmiany preferencji nabywców, zmiany w strukturze budżetów rodzinnych);

- wewnętrzne (zawodność techniczna i eksploatacyjna urządzeń, wrażliwość na zakłócenia zewnętrzne, niedostatki wiedzy kadry kierowniczej i personelu, kultura organizacyjna, postawy kadry kierowniczej, luka informacyjna o preferencjach i decyzjach podmiotów z otoczenia przedsiębiorstwa).

Ryzyko projektów innowacyjnych może być obniżone, jeśli wykorzystane zostaną dostępne narzędzia analityczne, $\mathrm{w}$ tym symulacje z zastosowaniem analizy Monte Carlo, metoda punktowa, analiza dyskryminacyjna, sieci neuronowe, algorytmy genetyczne $^{12}$, a także metody analizy portfelowej, której celem jest zbliżenie się do punktu optimum pomiędzy ryzykiem a atrakcyjnością projektu, przy jednoczesnym zachowaniu równowagi między rozwojem przedsiębiorstwa i jego produktami oraz przyjętą strategią ${ }^{13}$. Jednym z nowszych instrumentów analitycznych jest, wzorowana na matrycy General Electric, matryca (rys. 4) kojarząca prawdopodobieństwo porażki pomysłu ze skalą zagrożenia dla firmy/strategii w przypadku mylnego przewidywania.

W zależności od sytuacji rynkowej, rozmiarów i kondycji przedsiębiorstwa można zdecydować się na projekty względnie bezpieczne (strefa 3), niedające jednak znaczących efektów rynkowych, lub na bardzo ryzykowne projekty radykalne (strefa 1).

Prawdopodobieństwo pełnego sukcesu innowacji przemysłowej jest iloczynem prawdopodobieństw sukcesu technicznego i sukcesu rynkowego, pod warunkiem, że wystąpi sukces techniczny ${ }^{14}$. Projekty analizowane i oceniane są pod względem:

- konkurencyjności stosowanej technologii, dojrzałości technologicznej (fazy w cyklu życia);

- prawdopodobieństwa pełnego sukcesu, czyli zarówno sukcesu technicznego, jak i rynkowego;

- korzystności dla firmy, kształtowanej przez wiele czynników o różnej wadze, np.: zgodność z ogólną strategią firmy, oryginalność i jej znaczenie strategiczne oraz spodziewany czas eksploatacji przewagi konkurencyjnej, wysokość tworzonych barier, możliwości substytucji.

$12 \mathrm{~K}$. Janasz, Ryzyko i niepewność w projektach innowacyjnych, w: Innowacje w działalności przedsiębiorstw w integracji z Unia Europejska, red. W. Janasz, Difin, Warszawa 2005, s. 191-197.

13 T.J. Erickson, P.A. Roussel, K. Saad, Managing the link to corporate strategy - third generation R\&D,

A.D. Little Inc., Boston 1991, s. 93.

14 B. Nogalski, J. Rybicki, Strategiczne zarzadzanie firma, OPO-TNOiK, Bydgoszcz 1997, s. 114-116. 
Rysunek 4. Matryca oceny ryzyka projektu innowacyjnego

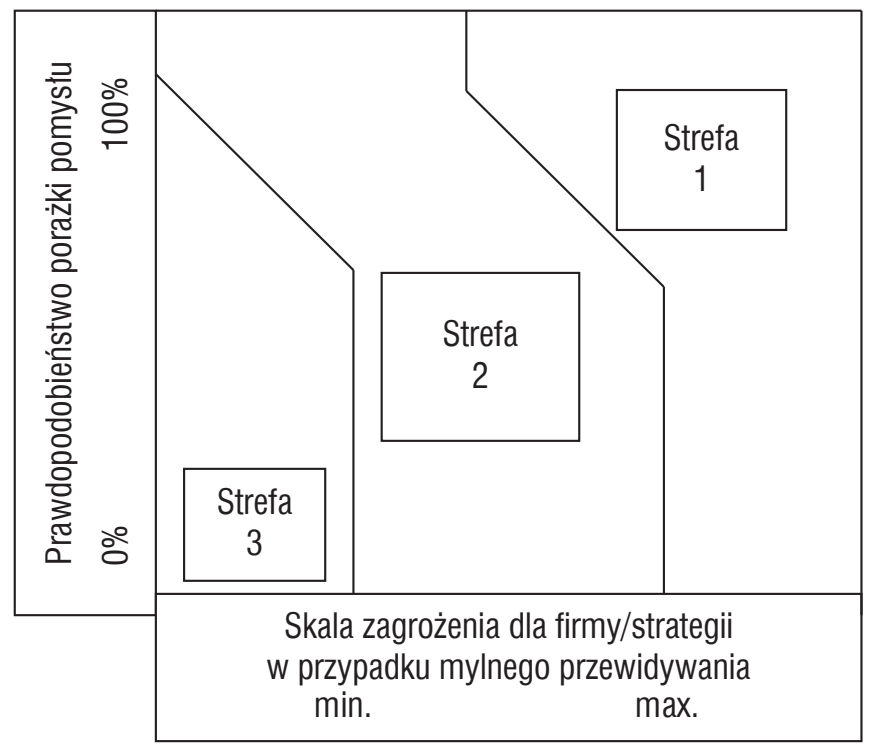

Źródło: Opracowanie własne na podstawie: S.D. Anthony, M.W. Johnson, J.V. Sinfield, E.J. Altman, Przez innowacje do wzrostu, Wolters Kluwer Polska, Warszawa 2010, s. 182.

Decyzje o rozpoczęciu projektu innowacyjnego powinny być podejmowane wówczas, kiedy zaistnieje duże prawdopodobieństwo, iż nakłady na wdrożenie innowacji $N_{i}$ będą mniejsze od możliwych do osiągnięcia korzyści:

$$
N_{i}<\Delta_{N B} * t
$$

gdzie:

$\Delta_{N B}$ - różnica w nakładach bieżących w jednostce czasu, powstająca w związku z eksploatacją przewagi konkurencyjnej, wytworzonej przez innowację, $t$ - czas eksploatacji innowacji.

Szczególną uwagę należy zwrócić na, będący efektem innowacji, wzrost konkurencyjności przedsiębiorstwa, a także na efektywność ekonomiczną. Problemem o zasadniczym znaczeniu jest wybór takiego projektu, który cechuje się wysoką efektywnością, a dochody z bieżącej działalności i możliwości pozyskiwania kapitału pozwolą na jego sfinansowanie. Podstawą decyzji może być też prognoza lub wyliczenie korzyści płynących z wdrożenia przedsięwzięcia. Sumaryczne efekty innowacji można wyliczyć, korzystając $\mathrm{z}$ formuły ${ }^{15}$ :

${ }^{15}$ I. Bielski, Innowacje w kreowaniu zdolności konkurencyjnej przedsiębiorstwa, „Rozprawy” nr 125, Wydawnictwa Uczelniane UTP im. J.J. Śniadeckich w Bydgoszczy, Bydgoszcz 2007, s. 72. 


$$
E=E_{w}+E_{t}+E_{s}+E_{z}+E_{p}+E_{u}+E_{k}+E_{m}+E_{e}-N-S
$$

gdzie:

E - suma efektów przedsięwzięcia innowacyjnego,

$E_{w}$ - efekty w kosztach wytwarzania, składające się z efektów w kosztach bezpośrednich produkcji i z efektu uzyskanego w wyniku wyeliminowania lub redukcji niektórych elementów kosztów pośrednich,

$E_{t}$ - efekty z tytułu skrócenia cyklu inwestycji (wyliczenia można dokonać, stosując metodę efektu brutto oszczędności z tytułu skrócenia czasu zamrożenia nakładów),

$E_{s}$ - efekty z tytułu uniknięcia lub zmniejszenia strat,

$E_{z}$ - efekty z tytułu zwiększenia produkcji,

$E_{p}$ - efekty z tytułu wykonywania prawa,

$E_{u}$ - efekty z tytułu uruchomienia produkcji nowego produktu,

$E_{k}$ - efekty konkurencyjne - wzrost zdolności konkurencyjnej jako wynik uczenia się przedsiębiorstwa,

$E_{m}$ - szacunkowe efekty marketingowe, na które składają się:

- efekty z tytułu zablokowania konkurencji aktualnej oraz wzrostu wartości barier wejścia,

- efekty z tytułu poprawy jakości produktu,

- efekty z tytułu wpływu nowej jakości oferty na wizerunek przedsiębiorstwa,

- efekty wynikające $\mathrm{z}$ wizerunku przedsiębiorstwa prowadzącego $\mathrm{B}+\mathrm{R}$,

- efekty z tytułu poprawy obsługi klienta, wynikające ze wzrostu zadowolenia i lojalności pracowników, a przekładające się na wzrost lojalności klientów,

- efekty z tytułu wzrostu sprzedaży produktów komplementarnych lub nawet niezwiązanych, produkowanych przez przedsiębiorstwo,

$E_{e}$ - efekty z tytułu ochrony środowiska obejmujące niezapłacone kary i odszkodowania oraz zmniejszone opłaty za korzystanie ze środowiska naturalnego,

$N$ - nakłady finansowe ${ }^{16}$,

$S$ - straty spowodowane wdrożeniem innowacji, między innymi spadek sprzedaży dotychczasowych produktów przedsiębiorstwa.

Możliwości odchyleń od zamierzonych wartości tkwią w każdym współczynniku wyróżnionym we wzorze. Ze względu na możliwość monitorowania i mierzenia efektów, można wyróżnić:

- efekty mierzalne i wyliczalne; często problemem staje się sam pomiar - łatwiej bowiem jest gromadzić te dane, które są łatwo dostępne, niż te, które są konieczne;

${ }^{16}$ Na szczególną uwagę zasługuje tutaj parametr nakładów finansowych - N. Przy projektach innowacyjnych finansowanych lub współfinansowanych z dotacji lub grantów może on nawet wynosić zero. 
- parametry stanowiące o jakości produktu i technologii, skrócony czas procesu, sprzedaż i udział w rynku, obniżenie kosztów produkcji, efekty z tytułu wykonywania prawa do patentów ${ }^{17}$;

- efekty szacunkowe - wzrost wartości i zdolności konkurencyjnej przedsiębiorstwa, wzrost sprzedaży związany z poprawą wizerunku, wzrost sprzedaży z tytułu poprawy jakości, poprawa bhp;

- efekty niemierzalne - poprawa jakości życia, rozwój wiedzy i kwalifikacji uczestników, zmiany w psychice uczestników procesu, poprawa stanu środowiska naturalnego.

\section{Ryzyko finansowe przedsięwzięć innowacyjnych dla polskich podmiotów gospodarczych}

Prowadzenie przedsięwzięć inwestycyjnych wiąże się z ryzykiem finansowym, czyli ryzykiem związanym z podejmowaniem decyzji finansowych dotyczących sposobów finansowania inwestycji. Najczęściej identyfikowane ryzyko finansowe to ${ }^{18}$ :

- ryzyko stopy procentowej,

- ryzyko walutowe,

- ryzyko inflacji,

- ryzyko kredytowe,

- ryzyko utraty płynności.

Modele finansowania projektów innowacyjnych w Polsce zmieniły się na przestrzeni ostatnich dziesięciu lat i obecnie cechują się znaczną różnorodnością. W związku z możliwościami pozyskiwania różnego rodzaju dotacji i grantów na innowacje zmienia się model finansowania projektów innowacyjnych. Wraz ze zmianą modelu finansowania oraz sposobów finansowania kolejnych etapów pojawia się również innego rodzaju ryzyko identyfikowalne na poziomie przedsiębiorcy.

1) Na etapie budowy koncepcji projektu najczęściej wykorzystywane jest finansowanie własne - jest to relatywnie mała skala inwestycji. Występujące tu najważniejsze ryzyko finansowe:

17 W. Kotarba, Z. Miklasiński, A. Pyrża, Nowe prawo wynalazcze, ZSE, Wektory Gospodarki, Warszawa 1993, s. 38.

18 Zarządzanie ryzykiem, red. K. Jajuga, PWN, Warszawa 2007, s. 18-24. 
a) ryzyko straty niewielkich środków finansowych (koszty np. zespołu projektowego), co może skutkować nawet utratą płynności - tylko w przypadku małego przedsiębiorstwa.

2) Na etapie badań i planowania projektu najczęściej wykorzystywane jest finansowanie własne, ostatnio połączone $\mathrm{w}$ wielu przypadkach $\mathrm{z}$ dotacjami na $\mathrm{B}+\mathrm{R}$ - jest to średnia lub duża skala inwestycji, w zależności od szczegółowości badań. Występujące tu najważniejsze ryzyko finansowe:

a) ryzyko straty znaczących środków finansowych (koszty badań, koszty zespołu projektowego itp.), szczególnie przy przeciągających się lub długotrwałych badaniach;

b) ryzyko otrzymania dotacji na $\mathrm{B}+\mathrm{R}$ po przygotowaniu koncepcji projektu;

c) ryzyko zwrotu dotacji na $\mathrm{B}+\mathrm{R}$ - przy źle wykonanym (nieosiągnięte parametry) lub źle rozliczonym projekcie badawczym.

3) Na etapie wdrożenia projektu najczęściej wykorzystywane jest połączenie finansowania własnego (wypracowanego zysku lub kapitału z: nowej emisji udziałów, akcji, wkładu własnego wspólników lub przedsiębiorców prowadzących działalność gospodarczą) z finansowaniem kapitałem obcym (kredyty, pożyczki, papiery dłużne itp.) oraz coraz częściej z dotacjami na wdrożenie projektów $\mathrm{B}+\mathrm{R}$ - jest to duża skala inwestycji. Występujące tu najważniejsze ryzyko finansowe (oprócz typowych makroekonomicznych, takich jak: ryzyko zmiany stóp procentowych, ryzyko walutowe, itp.) to:

a) ryzyko pozyskania finansowania zewnętrznego (pożyczki, kredyty, emisja papierów dłużnych itp.) - co w większości projektów finansowanych w sposób mieszany oznacza koniec projektu;

b) ryzyko zebrania wkładu własnego - przez podwyższanie kapitału przez obecnych przedsiębiorców/wspólników/udziałowców/akcjonariuszy lub przez nowe emisje (pozyskanie kapitału w private placement lub public placement) - najczęściej oznacza to koniec projektu;

c) ryzyko otrzymania w terminach zwrotu podatku VAT - urzędy skarbowe w Polsce czasami z różnych powodów kwestionują zasadność zwrotu podatku VAT lub prowadzą szczegółowe i długotrwałe postępowania sprawdzające;

d) ryzyko otrzymania dotacji i wypłaty środków dotacyjnych w zakładanych terminach - często nie ma precyzyjnie określonych terminów przelewania środków przez instytucje udzielające dotacji - jeżeli wielkość dotacji jest istotna dla projektu, brak wpływu może spowodować utratę płynności;

e) ryzyko uzyskania finansowania obrotowego - do rozpoczęcia produkcji zazwyczaj potrzebne są środki obrotowe; ich brak, np. z powodu nieprzewidzenia przez przedsiębiorcę, może spowodować niemożność pełnego wdrożenia projektu; 
f) ryzyko spełnienia zakładanych parametrów finansowych inwestycji innowacyjnej - może mieć dużo rozmaitych konsekwencji, np. wycofanie finansowania obcego, konieczność zwrotu dotacji.

\section{Zakończenie}

Ryzyko niepowodzenia jest nieodłącznym atrybutem procesów innowacyjnych. Dotyczy to zwłaszcza innowacji o dużym stopniu oryginalności, których wdrażanie odbywa się poza granicami wiedzy i doświadczenia projektowego, wytwórczego, marketingowego i inwestycyjnego. Głównym oczekiwanym rezultatem innowacji wdrażanych przez przedsiębiorstwo są pozytywne skutki na obsługiwanym rynku. Innowacje wywierają wpływ na rozwój wiedzy uczestników procesu innowacyjnego oraz rozwój przedsiębiorstwa, ale mogą też wywoływać skutki negatywne niezamierzone, szczególnie w środowisku naturalnym. Innowacje wdrażane przez przedsiębiorstwa składają się także na efekty obserwowane w skali makro, głównie zaś wzrost inwestycji, wzrost zatrudnienia i PKB. Przygotowanie skutecznej strategii innowacyjnej przedsiębiorstwa wymaga nie tylko znajomości i umiejętności zastosowania wiedzy interdyscyplinarnej, ale także znajomości rodzaju, obszaru i rozmiarów skutków będących następstwem innowacji. Wydaje się jednak, że celowe byłoby włączenie do rozważań na temat ryzyka związanego $\mathrm{z}$ wdrażaniem innowacji także pogłębionych, wieloaspektowych analiz ryzyka zaniechania w tym obszarze. Ryzyko finansowe przedsięwzięć innowacyjnych może być obniżone, do akceptowalnego poziomu, tylko w oparciu o wnioski wynikające z precyzyjnej analizy otoczenia technologicznego i kontekstu rynkowego wdrażanej innowacji.

\section{Literatura}

Anthony S.D., Johnson M.W., Sinfield J.V., Altman E.J., Przez innowacje do wzrostu, Wolters Kluwer Polska, Warszawa 2010.

Bacior M., Kreowanie wartości firmy jako cel zarządzania współczesnym przedsiębiorstwem, CeDeWu, Warszawa 2015.

Bielski I., Innowacje w kreowaniu zdolności konkurencyjnej przedsiębiorstwa, „Rozprawy” nr 125, Wydawnictwa Uczelniane UTP im. J.J. Śniadeckich w Bydgoszczy, Bydgoszcz 2007. 
Bielski I., Współczesny marketing. Filozofia, strategie, instrumenty, Studio Emka, Warszawa 2006.

Block S.B., Hirt G.A., Foundations of Financial Management, Irwin, Homewood 1987.

Brzuchowski E., Ciągi myśli i czynów, „Mechanik” nr 9, 1983.

Cooper R.G., The Dimensions of Industrial New Product Succes and Failure, „Journal of Marketing" Vol. 43, Summer 1979.

Cooper R.G., Winning at New Products, Addison Wesley, Reading, MA, USA 1993.

Czekaj J., Dresler Z., Podstawy zarządzania finansami firm, PWN, Warszawa 1995.

Efektywność przedsięwzięć rozwojowych, red. R Borowiecki, Wydawnictwo AE w Krakowie, TNOiK, Warszawa, Kraków 1995.

Ehrlich A., Ryzyko gospodarcze, w: Encyklopedia organizacji i zarządzania, PWE, Warszawa 1981.

Erickson T.J., Roussel P.A., Saad K., Managing the link to corporate strategy - third generation R\&D, A.D. Little Inc., Boston 1991.

Harry M., Schroeder R., Six Sigma. Wykorzystanie programu jakości do poprawy wyników finansowych, Dom Wydawniczy ABC Oficyna Ekonomiczna, Kraków 2002.

Janasz K., Ryzyko i niepewność w projektach innowacyjnych, w: Innowacje $w$ działalności przedsiębiorstw w integracji z Uniq Europejska, red. W. Janasz, Difin, Warszawa 2005.

Korczak J., Wybrane aspekty ryzyka $w$ łańcuchu logistycznym, w: Wybrane zagadnienia z zakresu transportu i logistyki, red. A. Montwiłł, Wydawnictwo Uczelniane WSG, Bydgoszcz 2013.

Kotarba W., Miklasiński Z., Pyrża A., Nowe prawo wynalazcze, ZSE, Wektory Gospodarki, Warszawa 1993.

Lancaster G., Massingham L., Marketing Management, McGraw-Hill, London 1993.

Marczyk J., Czarnota J., Gliński J., Wzrost złożoności jako sygnał ostrzegawczy, „Harvard Business Review Polska” listopad 2010.

Nogalski B., Rybicki J., Strategiczne zarządzanie firmą, OPO-TNOiK, Bydgoszcz 1997.

PN-IEC 60300-3-9, 1999.

Pszczołowski T., Mała encyklopedia prakseologii i teorii organizacji, Ossolineum, Wrocław, Warszawa 1978.

Ries A., Trout J., 22 niezmienne prawa marketingu, S. „Marketing bez tajemnic”, PWE, Warszawa 1997.

Zarządzanie ryzykiem, red. K. Jajuga, PWN, Warszawa 2007. 


\section{Innovative projects in a company as a potential source of financial risk}

Increase in the value of a company is related to implementation of innovative processes in all functional areas of business. As a result of implemented innovation, the company may offer new products or lower prices. In any case, this leads to improved economic efficiency of the company. The rise in innovation is coupled with an increase in the benefits but is also accompanied by an increase of the risk of failure. This constitutes background against which the article presents the course of innovation processes and possibilities of applying innovation in different market strategies. The article stresses relations between financial risk and the time of innovation. Sources of financial risk and methods of financing innovative investments are also discussed as is the need to take into account the technological environment and market context of innovation.

Keywords: innovative processes, market context, sources of financial risk, goodwill

\section{Projets innovants dans les entreprises comme une source de risques financiers potentiels}

L'augmentation de la valeur de l'entreprise est liée à la mise en œuvre de processus innovants dans tous les domaines fonctionnels de l'entreprise. Grâce à la mise en œuvre de l'innovation, l'entreprise peut offrir des produits distinctifs ou des prix plus bas. Dans tous les cas, cela conduit à une amélioration de l'efficacité économique de l'entreprise. Avec la montée des innovations, il y a une augmentation des avantages, mais aussi une augmentation du risque de faillite. Dans ce contexte, l'article présente le cours des processus d'innovation et la capacité à utiliser l'innovation dans les différentes stratégies de marché. L'article a souligné les relations entre le risque financier et la période de l'innovation. Il examine aussi les sources de risque financier et les moyens de financer des investissements innovants. Il indique la nécessité de prendre en compte l'environnement technologique et le contexte du marché de l'innovation.

Mots-clés: processus innovants, contexte du marché, sources de risques financiers, écart d'acquisition 


\section{Инновационные проекты на предприятиях как потенциальный источник финансовых рисков}

Увеличение стоимости предприятия связано с реализацией инновационных процессов во всех функциональных областях бизнеса. В результате реализации инноваций предприятие может предложить новые продукты или более низкие цены. В любом случае это приводит к повышению его экономической эффективности. С повышением степени новизны инновации происходит увеличение как преимуществ, так и риска. В этом контексте статья представляет ход инновационных процессов и возможности использования инноваций в различных рыночных стратегиях. Указываются отношения между финансовым риском и продолжительностью инноваций, а также обсуждаются источники финансового риска и способы финансирования инновационных инвестиций. Подчеркивается необходимость учитывать технологическую среду и рыночный контекст инноваций.

Ключевые слова: инновационные процессы, контекст рынка, источники финансового риска, гудвилл 